\title{
Design and Reconstruction of an Ancient Roman Crane
}

\author{
Marco Ceccarelli \\ Department of Industrial Engineering, University of Rome Tor Vergata, Rome, Italy \\ Email: marco.ceccarelli@uniroma2.it
}

How to cite this paper: Ceccarelli, $M$. (2020). Design and Reconstruction of an Ancient Roman Crane. Advances in Historical Studies, 9, 261-283.

https://doi.org/10.4236/ahs.2020.95021

Received: October 30, 2020

Accepted: December 5, 2020

Published: December 8, 2020

Copyright $(\odot 2020$ by author(s) and Scientific Research Publishing Inc. This work is licensed under the Creative Commons Attribution International License (CC BY 4.0).

http://creativecommons.org/licenses/by/4.0/

\begin{abstract}
Archeological remains and literature sources are used to work out design considerations and reconstruction activities on an ancient Roman crane. Design requirements have been elaborated by looking at the Vitruvius work as republished during Renaissance and considering practical aspects of material and manufacturing both in ancient time and today possibilities. Results are reported in terms of design developments and experiences for prototype reconstructions that have been exhibited in a museum.
\end{abstract}

\section{Keywords}

History of Machines, Ancient Roman Cranes, Historical Analysis, Reconstruction Design

\section{Introduction}

Ancient Roman machines attract great attention not only for their specific designs of relevant interest for the History of Engineering and Technology, but also for the surprising levels of technology that can be identified in those solutions.

Historical literature has been elaborated to track machinery evolution with analysis of designs and products as part of the mankind history in which Roman machine engineering and technology are recognized of relevant importance and impact even as a basis for modern western world, in encyclopedic works like for example in (Capocaccia 1973), (Singer et al. 2012) and in monographic works like for example in (Burstall 1963), (Galli \& Pisani Sartoro, 2009), (Russo \& Russo, 2009), (Rossi et al., 2009), (Di Pasquale, 2019). Specific attention has been also addressed to specific Roman machine technology by looking at specific machines with details on mechanical design and usage, like for example in (Meighorner-Schardt \& Blumenthal, 1989), (Martines, 1999), (Ceccarelli \& De 
Paolis, 2008), (Molari et al., 2016). A direct of experience by the author with a multidisciplinary teamwork is reported in (Ceccarelli et al., 2019) referring to an investigation of ancient Roman ball bearings looking at their design, manufacturing, and usage.

Nevertheless, there are still aspects to be discovered or better investigated on Roman machines as indicated also in exhibitions of machine reconstructions like those illustrated in (Galli \& Pisani Sartoro, 2009), (Di Pasquale, 2019).

The significance of an investigation for reconstruction purposes on ancient Roman cranes can be understood not only for a specific historical interest on their design and operation but even for better understanding of the level of ancient technology both from theoretical and practical expertise. It is well understood that thanks to a high machinery technology the Roman engineers could design and operate complex machines successfully as outlined for example in (Rossi et al., 2009). Specific attempts are still proposed to better understand and then to give design reconstructions of Roman cranes, like for example in (Meighorner-Schardt \& Blumenthal, 1989) and (Molari et al., 2016).

This paper is an expanded version of a paper (Ceccarelli, 2020) that was presented in September 2020 at the IFIT2020 Conference of IFToMM Italy in tele-conference mode with outlines of activities for a new reconstruction of a general Roman crane with a calcatoria (treadmill) wheel. In this paper, results are presented from activity with investigations, design, and prototype construction on ancient Roman cranes by looking at archeological sources and literature on ancient machines with the aim to develop a design reconstruction with practical solutions for a prototype to be exhibited and in future to be used in performance experimental characterizations. Main literature references are considered from Vitruvius work, as reported in in (Fra' Giocondo, 1513), (Cesariano, 1521), (Fleury, 1993) also with modern interpretation as in (Cigola \& Ceccarelli, 2014, 2016). The rest of this paper is organized as follows: Section 2 presents an outline to discuss historical sources on Roman cranes; Section 3 outlines arguments for requirements and design solution for a practical design in modern time representing a Roman crane; and Section 5 shows the results with a built prototype with main characteristics to be further investigated in future testing activity.

\section{Archeological and Literature Sources}

Since ancient Roman machines were made at the most of perishable wood materials, there are no remains of ancient Roman cranes and only small parts of components have been found in archeological explorations like pulleys, cable pieces, and iron reinforcements and nails as coming even not only from crane machines. Main direct sources of Roman times on design of ancient Roman cranes can be found in artistic representations and other information can be extracted from a literature that has been rediscovered and reinterpreted in the Renaissance, mainly referring to Vitruvius work. All of them have been used in this work as references for the analysis and reconstruction activity of an ancient Ro- 
man crane and the used ones are discussed in the following. Those crane machines can be considered basic tools for the ancient Roman engineers to design and operate large cranes that were used to build buildings also of considerable size all around the Roman empire, like for example the Colosseum and Pantheon temple in Rome.

Figure 1 and Figure 2 show the main archeological artistic references for this work as artistic representations of ancient Roman cranes, namely the so-called Haterii crane, Capua basso-relievo (bas-relief), Terracina basso-relievo (bas-relief), and so-called Neron tomb terracotta. Those artistic representations do not seem to have specific aims of disseminating technical solutions, also in consideration of the several other information that is reported in them as being part of tomb artistic furniture. They can therefore be more appropriately interpreted as celebrations in memory of how the referenced person in the representation has achieved a social-political success. But they can be also evaluated in giving, somehow in secondary way, light and importance to the technique of machines, despite the fact that in the ancient world the technique was not generally considered for social political reputation, as pointed out in the humanistic literature on the History of ancient technology and for example in (Ceccarelli \& De Paolis, 2008). In fact, in the Haterii tomb in Figure 1(a) the crane is placed at the edge of the representation somehow as a decorative but impressive part of the overall scenario, likewise also in the Capua basso-relievo in Figure 1(b) and in the Neron tomb terracotta in Figure 2(b), whereas in the Terracina basso-relievo in Figure 2 (a) the crane is even in the back of the scenario.

In particular, the so-called Haterii crane in Figure 1(a) is from the tomb of Haterii family that Quintius Haterius Tychicus committed about in $100-120$ A.D. along the ancient labicana road in Rome with information summarized in (Di Pasquale, 2019). The represented crane of large size with several hoists, a large turning head, and a large driving (calcatoria-treadmill) wheel with several humans is very likely a memory of the cranes that the commitment used for the works in the construction of the Colosseum in Rome. The basso-relievo is today archived and exhibited at the Vatican Museum in Vatican City. The crane design is characterized by a calcatoria wheel of a size permitting the operation several calcators (operators) simultaneously with a design showing 8 spokes of the 13 ones that very likely are the supporting structures. In addition, several pulley blocks are represented that show several cables coming in and out for the presence of several pulleys as per the high loads the crane could lift as very likely with stone blocks up to 8 tons.

The Capua basso-relievo Relief in Figure 1(b) is a commemorative plate of Luccesius Pecularis, who committed it to record his commitment for the works repairing the Capua theater vey likely between 112 and 94 B.C., (Di Pasquale, 2019).

Today it is preserved at the Provincial Museum of Campania in Capua. The representation shows aside a calcatoria wheel with 11 spokes hosting two slaves for actuating the cables in the crane beam that is in the back lifting a column. 


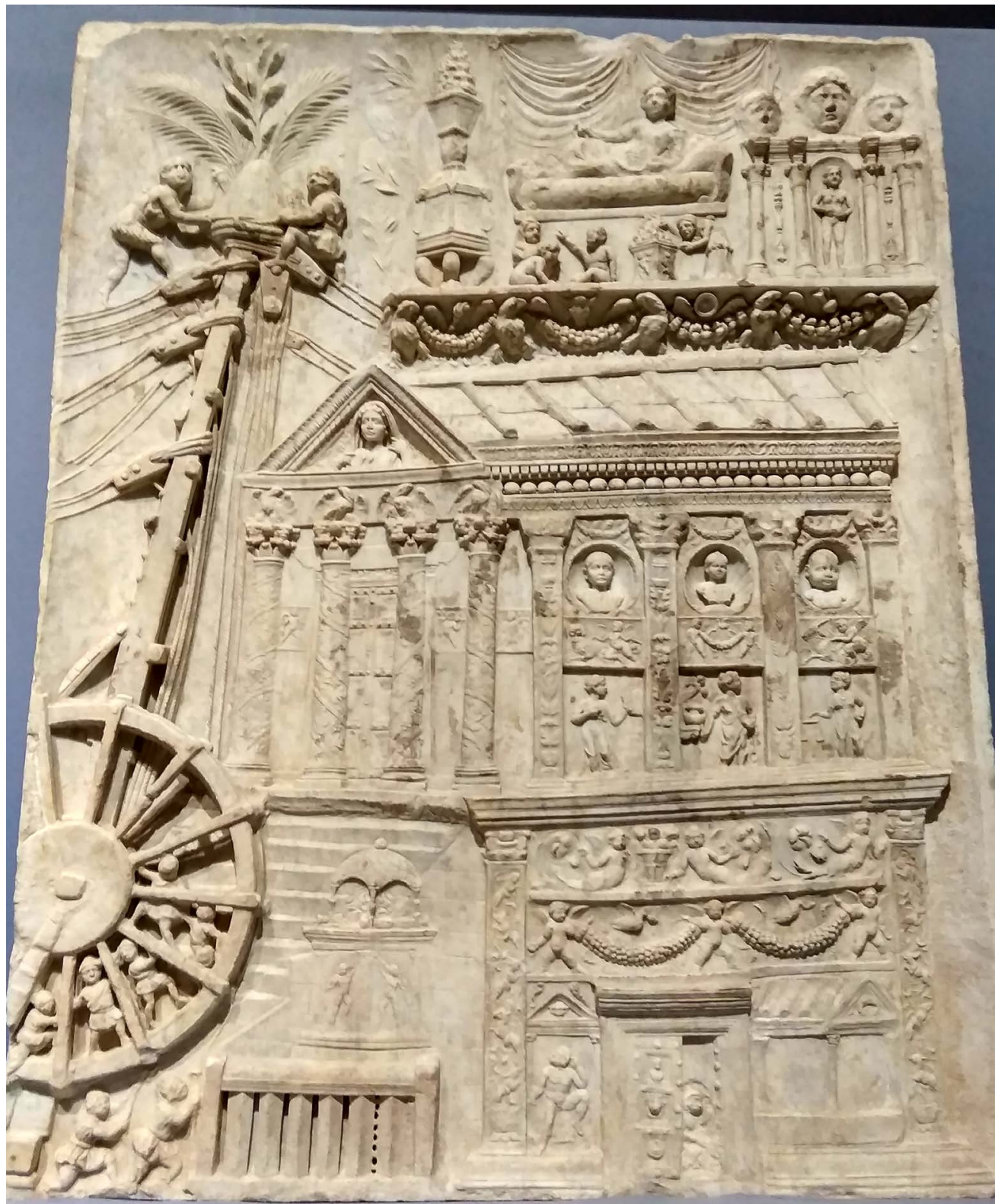

(a)

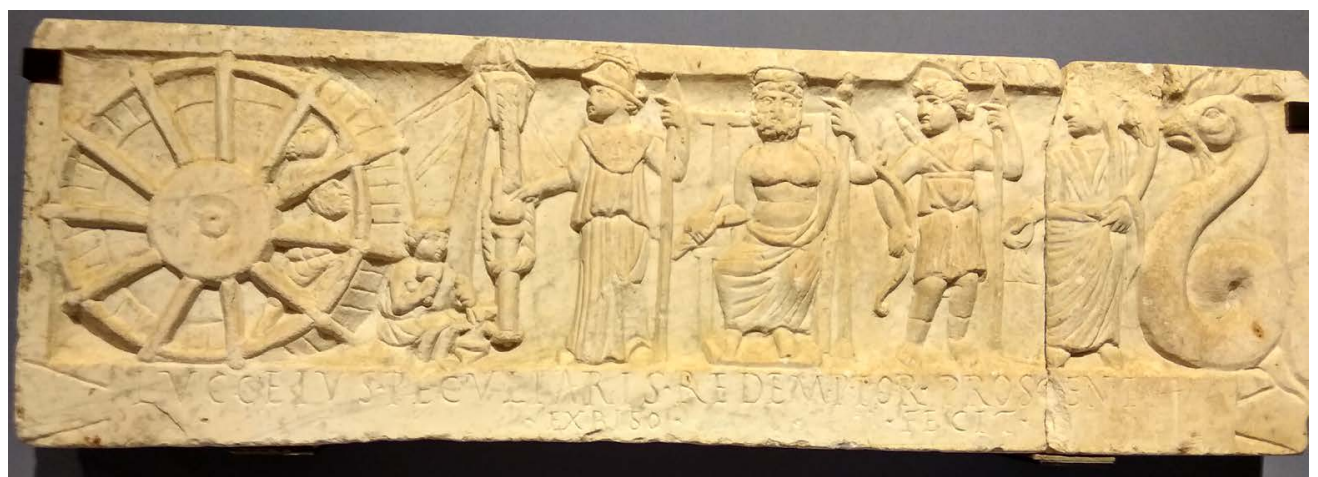

(b)

Figure 1. Archeological sources of ancient Roma cranes with calcatoria wheel in: (a) Haterii tomb of I B.C.; (b) Capua basso-rilevo of II A.D. 


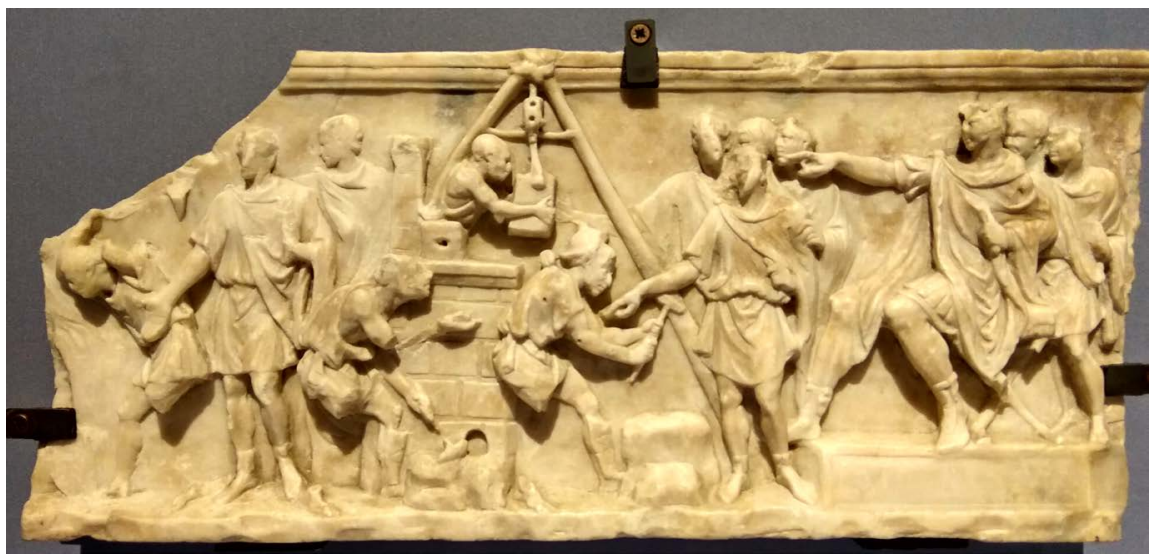

(a)

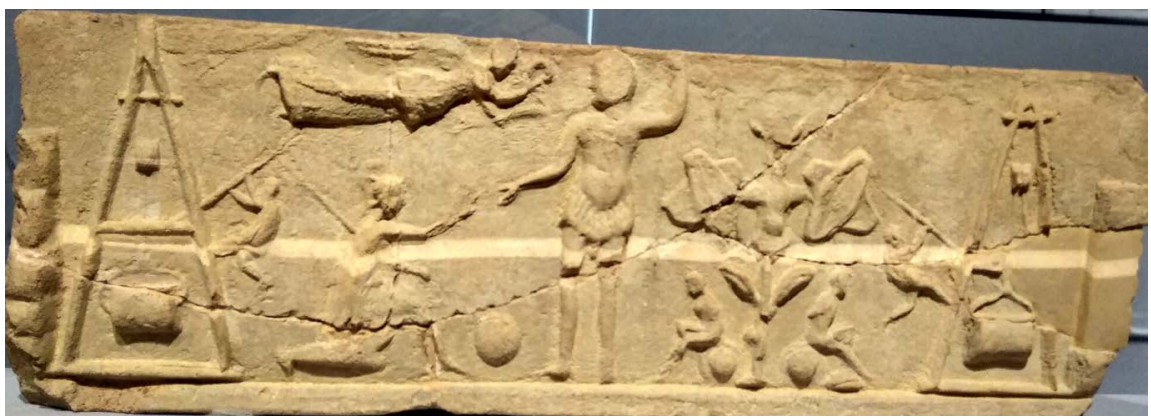

(b)

Figure 2. Archeological sources of ancient Roma cranes with simple structure in: (a) Terracina basso-rilevo of I B.C.; (b) Terracotta from so-called Nerontomb of I B.C.

The Terracina basso-rilievo in Figure 2(a) is from a plate discovered near the port of Terracina (100 km south of Rome) with information summarized in (Di Pasquale, 2019). It is dated around $41-36$ B.C as referring to the memory of a magistrate (at the center of the scenario on a seat), who was responsible for the constructions of a new colony. The represented crane looks to be a simple one with portable features to move and precisely locate not very large stone blocks as shown to be operated by negroid slaves in different operation with it. It is preserved and exhibited at the National Roman Museum in Palazzo Massimo in Rome.

The terracotta in Figure 2(b) was found at the so-called tomb of Nero that is dated in the late republican period of I B.C and it is preserved at the National Roman Museum Palazzo Massimo in Rome, (Di Pasquale, 2019). The representation shows a victory scene in which two small cranes (of goat crane type) are in operation lifting stone blocks that are grasped by large two-finger grippers to build a wall by a the action of an operator acting on its winch by a long rod.

Figure 3 shows archeological remains of wood pulley blocks that could be used in ancient Roman cranes indicating both the theory and design of pully systems for handling large loads. In fact, Figure 3(a) shows the remain of a pulley block from the two imperial Roman ships that were found in the lake of Nemi (30 km south of Rome) in 1930s, (Ucelli, 1950) and today the remains are 


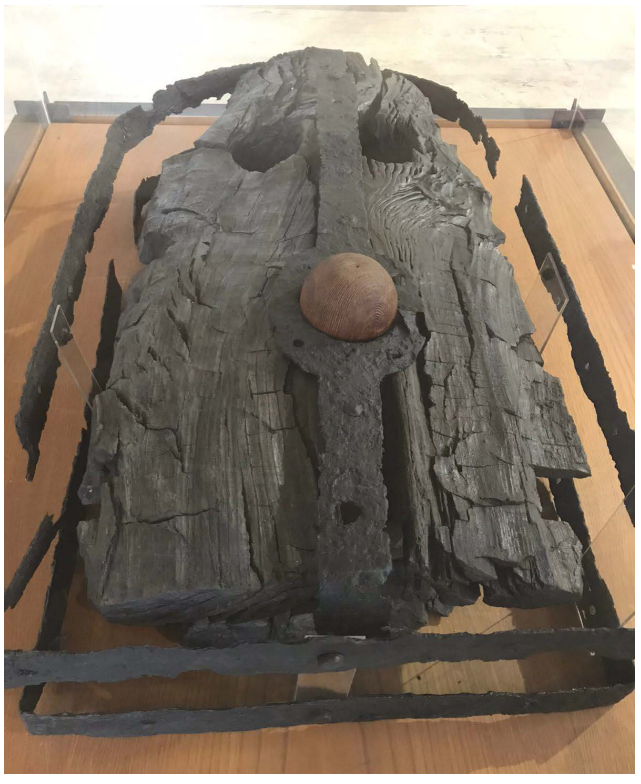

(a)

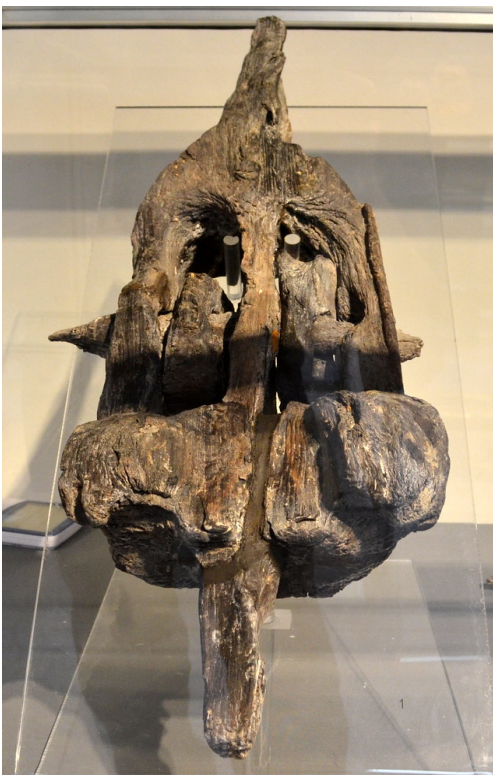

(b)

Figure 3. Archeological remains of pulley system for ancient Roma cranes from: (a) Imperial Roman ships in Nemi lake of II A.D.; (b) Kenchreai port of Ancient Corinth of IV A.D.

preserved and exhibited in the Museum of Roman ship there. The two imperial Roman ships were used very likely one as a temple and the other as summer villa by Caligula emperor in the II century A.D. The pulley block is made of wood body that is reinforced by an external iron frame and the overall size of $80 \times 108$ $\times 28 \mathrm{~cm}$ indicates its design for a use in lifting high loads or governing the large helm of the large ships.

The wood pulley block in Figure 3(b) was found with a series of opus sectile panels, in the "Temple of Isis" on the south port-mole at Kenchreai, Turkey, with remains dated in IV A.D., (Shaw, 1967), and todays is preserved at the Archaeological Museum of Isthmia, Greece. The pulley block is made of a wood body with overall size of $19 \times 71 \times 15 \mathrm{~cm}$ indicating its design for a use in lifting high loads either for port applications or repairing works of the temple where it was found.

The literature sources refer to the reprints of the few Roman works on machine technology and at the most on liber X od the De Architectura by Vitruvius, (Cigola \& Ceccarelli, 2014, 2016). The main published editions of the Vitruvius work that can be considered also for refence of the crane machines, can be listed as, (Cigola \& Ceccarelli, 2014):

- 1486 by Sulpicio da Veroli and Pompolio Leto, edited in Rome ("Editio princeps" 1)

- 1496 Florentine edition

- 1497 Veneto region edition

- 1511 by Frà Giocondo, edited in Venice (first illustrated edition)

- 1521 by Cesare Cesariano, edited in Como (first commented and illustrated 
edition)

- 1524 by Durantino, edited in Venice

- 1536 by Giovan Battista Caporali, edited in Perugia

- 1547 by Jean Martin and Jean Gujon, edited in Paris (first French edition)

- 1552 by Guillaume Philandrier, edited in Lion (first commented French edition)

- 1556 by Daniele Barbaro, edited in Venice

- 1564 by Lazaro de Velasco, manuscript (first Spanish translation)

- 1575 by Walther Hermann Ryff, edited in Basel (first German edition)

- 1582 by Miguel de Urrea, edited in Alcala de Henares (first Spanish edition)

- 1624 by Henry Wotton edited in Amsterdam (first English translation)

- 1660 by Giovanni Antonio Rusconi, edited in Venice

- 1673 by Claude Perrault, edited in Paris

- 1739-1741 by Giovanni Poleni, edited in Padua

- 1771 by William Newton edited in London (first English edition Books 1 - 5)

- 1790 by Bernardo Galiani, edited in Siena and Naples

- 1791 by William Newton edited in London (first English edition ten Books)

- 1831-1832, by Quirico Viviani, edited in Udine.

In modern times several other studies and re-interpretation of Vitruvius work were published with the full text and its interpretation figures, and they are still today source of debates. The most accredited recent one is the one in (Fleury, 1993) that was used as reference also in this work. It is to note that the machine drawings in all the published reprints of Vitruvius works are results of interpretations of the Latin text, containing also technical terms that are still to be fully understood.

The consideration of literature sources has been worked out looking also to practical aspects for the feasibility of crane constructions at the Roman time in conjunction to the above mentioned inspiration from archeological remains and taking into account also the time the authors of the reprints.

In particular, Figures 4-6 show examples of literature sources referring to Vitruvius work, as referring to crane structures as interpreted over the time with significant solutions that are summarized recently as in Figure 7 with a main wood structure of beams that once fixed on the ground with several cables can afford a load that is lifted thanks to a pulley system with small orientation mobility.

In Figure 4(a) the first drawing is shown from first interpretation of the translated text by Frà Giocondo in 1513 indicating the main components of a basic Roman crane with a static supporting beam structure that is equipped with a well clear pulley system that is driven by one movable vertical capstan through an horizontal drum. Figure 4(b) from the Cesare Cesariano's publication in 1521 shows a very articulated crane, very likely drawn by the expert machine engineer Francesco di Giorgio as one of the first and most successful early reconstruction with clear inspiration to practical applications of the Renaissance. 


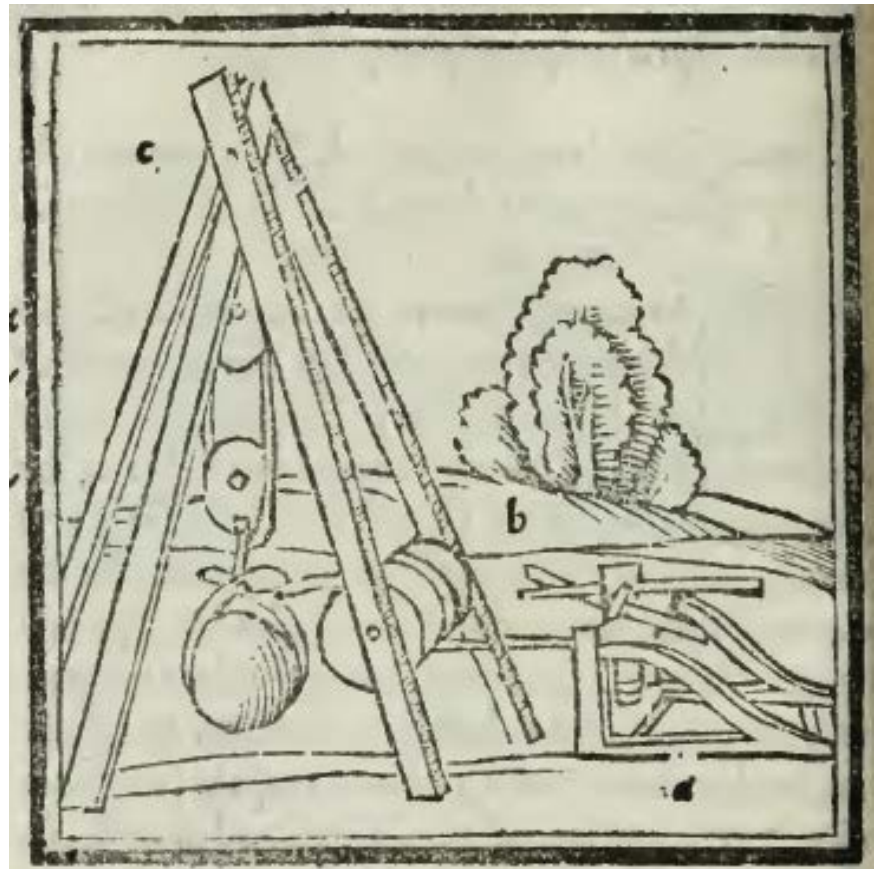

(a)

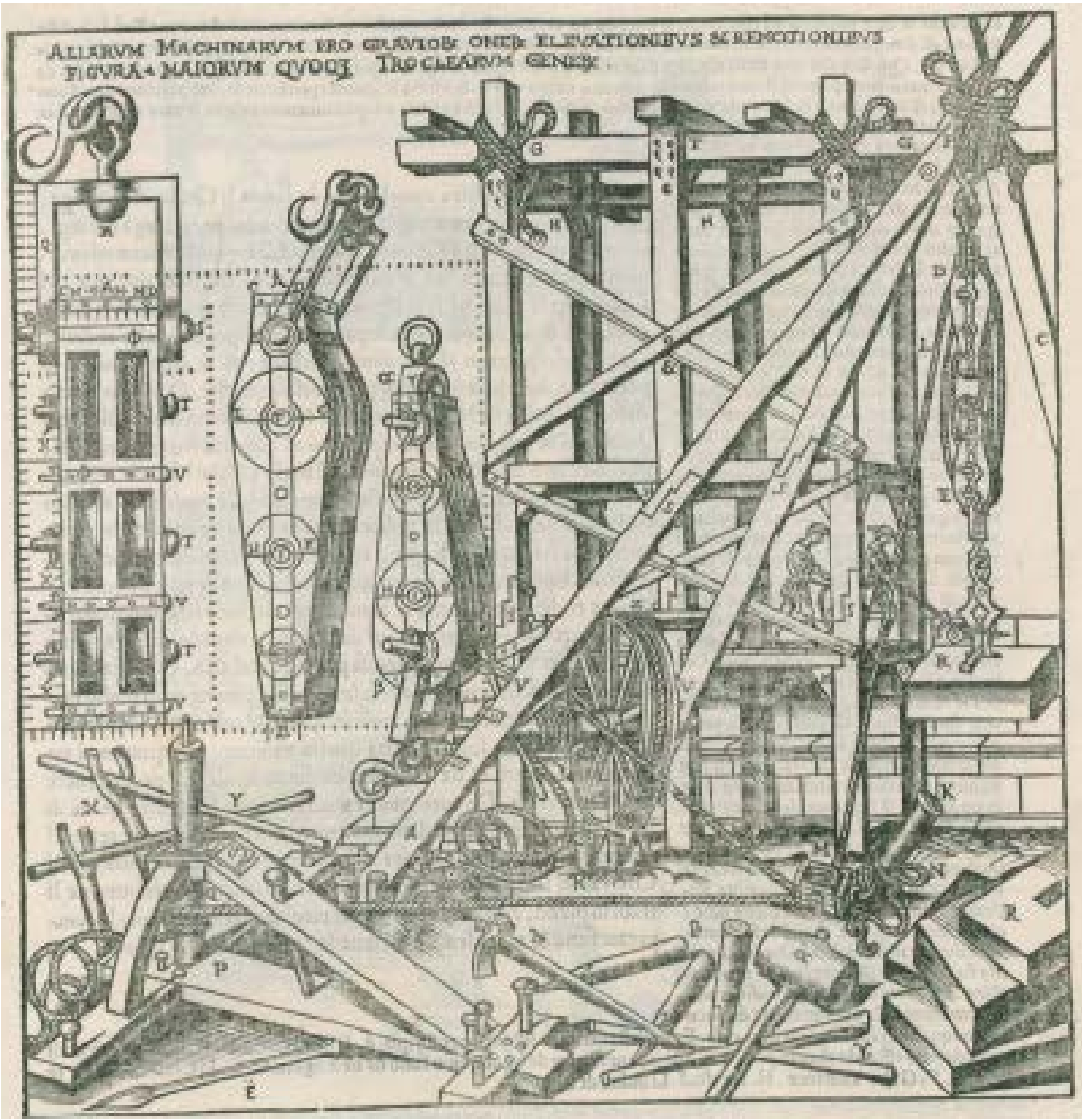

(b)

Figure 4. Reconstruction drawings of ancient Roma cranes from liber X of Vitruviusby: (a) Frà Giocondo in (1513); (b) Cesare Cesariano (1521). 
The representation shows all the elements of a very efficient crane of large size with several details in the pulley blocks for several cable returns, a vertical axis capstan governing perhaps the lifting cable in the pulley block, whereas a large wheel that is not clearly a calcatoria wheel handles a cable too.

Figure 5 from the Vitruvius reproduction by Daniele Barbaro in 1594 shows even more clearly all the components of a first type of Roman cranes focusing the attention on the pulley system with several pulley blocks. In addition, interesting details are given for the wood connection and fixings of the crane beams among them and in the ground by means of pins and ropes. Capstan and drum in the crane are also shown with handles for manual operation. At the bottom of the figure concepts for the force transmission and balance are shown using levers and scales.

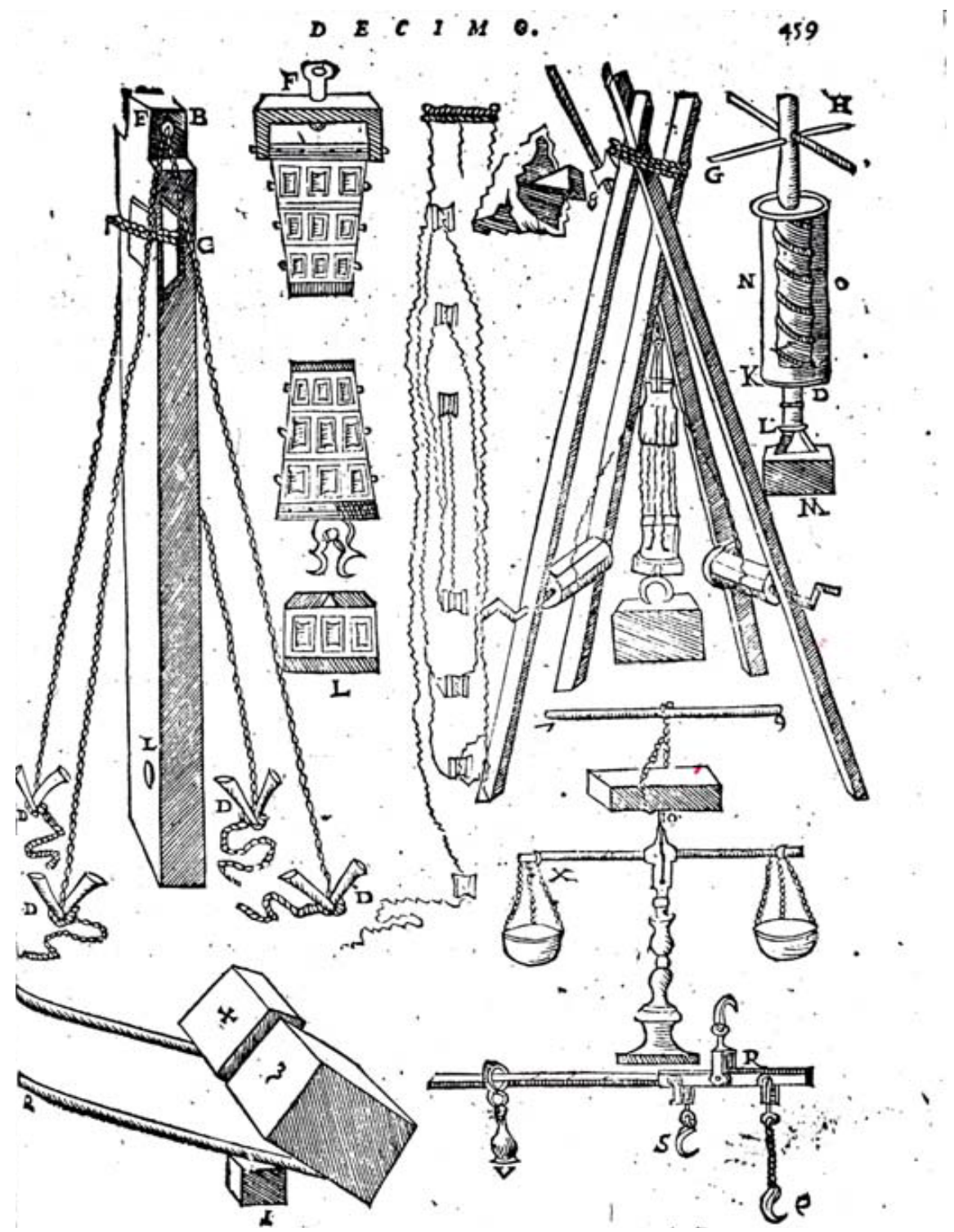

Figure 5. Reconstruction drawings of ancient Roma cranes from liber X of Vitruvius by Daniel Barbaro in (1584). 
Figure 6(a) shows a crane drawing from Rusconi edition in 1660 with clear indication of the design elements and operation features by focusing on a tripod beam structure, a pulley system with two pulley blocks with several rope returns, a gripper mechanism, a calcatoria wheel with 8 spokes hosting one calcator for driving the rope lifting a load. The wood connections are drawn as a pin for the vertex fixing of the tripod structure and as supporting frames of the calcatoria wheel axis on the tripod beams.

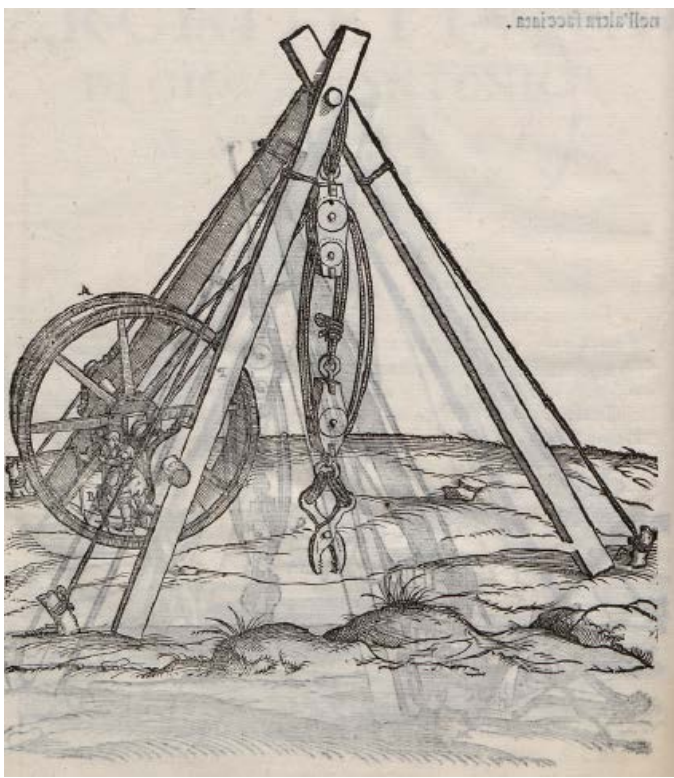

(a)

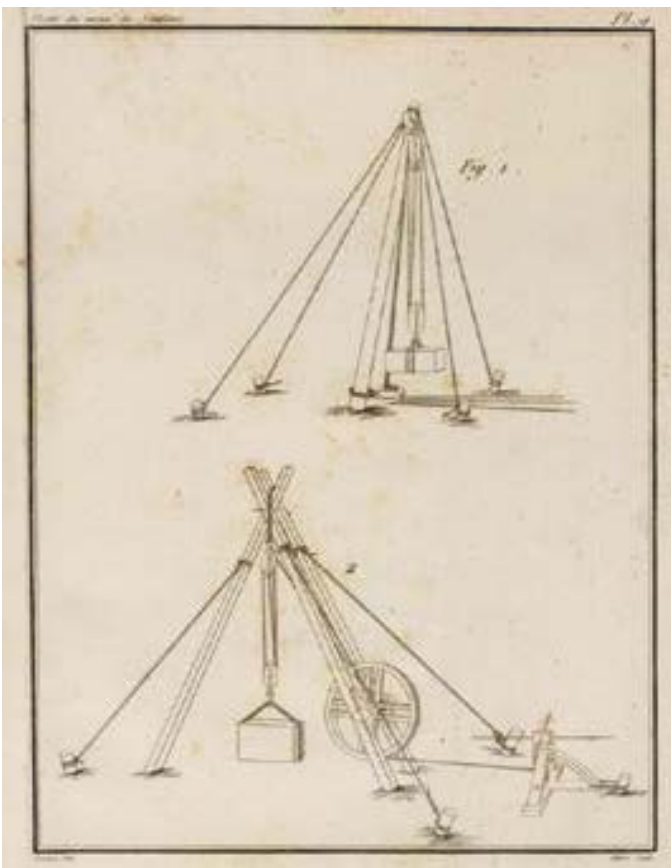

(b)

Figure 6. Reconstruction drawings of ancient Roma cranes from liber X of Vitruvius by: (a) Rusconi (1660); (b) Gian Antonio Borgnis (1818). 
Interesting is the Figure $6(\mathrm{~b})$ from the specific volume on load lifting machines the encyclopedic machine handbook by Borgnis in 1818 in which referring to historical sources for those time solutions, the Vitruvius cranes are considered in their most recognized design structures as a light two-beam crane and a powerful tripod structure equipped with calcatoria wheel and external capstan. However the design drawing is not completely clear mainly referring to the calcatoria wheel that is depicted with only 4 spokes and not a clear function, very likely mixing its feature between powering the rope load lifting and with or without actions from an external capstan. This is an example of how the Vitruvius crane designs were indeed used practically over time, with their essential characters even in modern times.

Figure 7 from the Vitruvius reproduction by Fleury in 1993 has been considered in this work for its character of modern summary of the interpretations of Roman cranes in a huge literature that the above Figures 4-6 illustrates with significant examples sometimes with more details in practical construction aspects. The figure shows the three categories of Roman cranes that can be understood from the Vitruvius survey of machines in its chapter X of De Architectura. Again, the main components can be recognized in large wood beams (black depicted) that make the structure arranged in different way depending of the values and size of the load to be lifted as well as the expected movements. $\mathrm{Cu}$ riously the first crane is made of one beam only but very likely to stress its portability. The other two categories for increased load capacity are both made of two beams and none is depicted with the tripod structure very recurrently in previous reproductions. In all the case the fixing of the beam structure is achieved with 4 ropes with pins/rods that are inserted in the ground. The pulley systems are depicted differently in the three cranes indicating also different operation modes. Namely in the first one the ropes coming out of the lifting pully system are finally guided out of the crane by means of a pulley block at the bottom of the beam for unspecified driving action. In the second crane the pulley blocks are detailed with a quite simple design with two pulleys in the fixed top
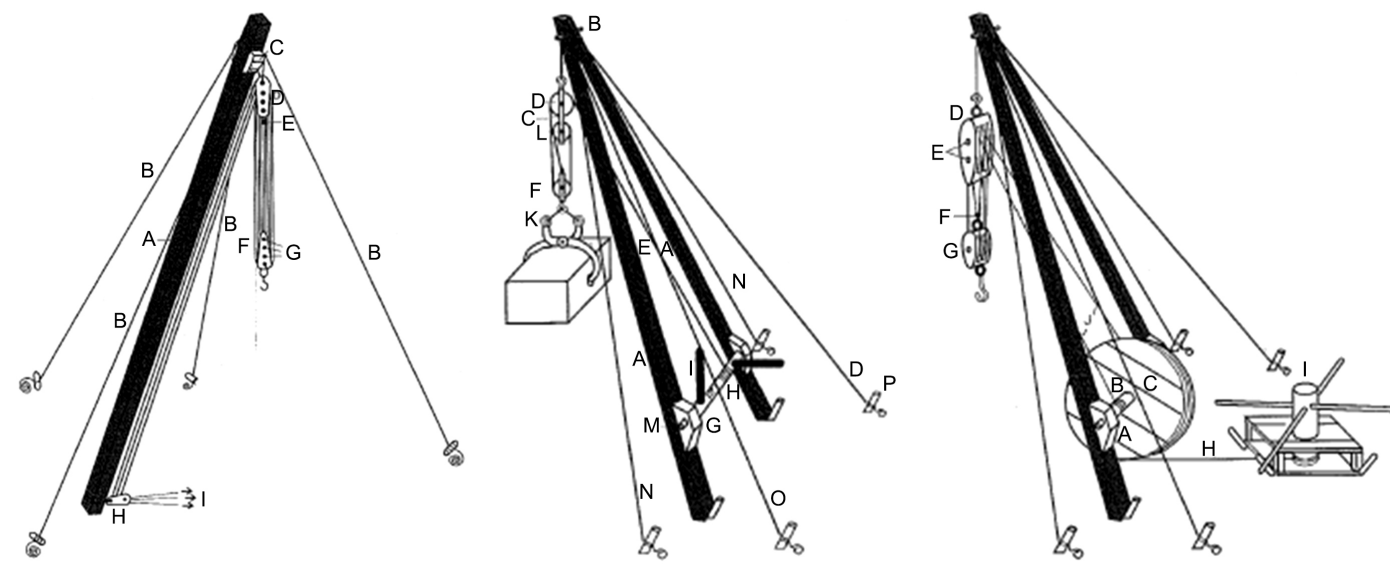

Figure 7. Reconstruction drawings of ancient Roma cranes from liber X of Vitruvius by Philippe Fleury (1993). 
pulley block and the lifting rope is activated by the action of an axle-drum with two handles for manual operation. The drum axle is attached to the beam by two wood supporting frames hosting the rolling axle. This second solution clearly indicates a large load capacity that is also stressed by the large block that is drawn as grasped by a two-finger gripper. In the third crane the pulley system looks similar to the one in the first crane but with larger design and more rope returns. The third crane is characterized by a large calcatoria wheel driving a rope to the pulley block and an external large capstan.

However, the calcatoria features is not evident since the large wheel is depicted as a tabled wheel. Its axle is shared with the rope drum with an additional rope going to the pulley block making confusing the action of the pulley block with two driving ropes. In addition, the external capstan seems to actuate again the large wheel. However, the large power of this crane is clearly indicated by the presence of the large calcatoria wheel and the capstan. Curiously this third cane like the first one is equipped with a hook in the moving pulley block to attached load. But there are not archeological evidence that Roman cranes were equipped with hooks (that indeed were well developed only after the mid of $19^{\text {th }}$ century) but they used cranes with more likely grippers to grasp the stone blocks, and therefore this can indicated that still in modern time the interpretations of the Vitruvius cranes are worked out looking at their practical applications.

In summary the literature, mainly referring to Vitruvius work De Architectura in its chapter (Liber) $\mathrm{X}$ refers to three types of the cranes that indeed can be recognized also in the archaeological remains with solutions from portable designs or small load capacity and limited movements up to large powerful designs that were equipped with large calcatoria wheel and capstans.

\section{Requirements for Reconstruction Design}

A today modern reconstruction of an ancient machinery depends strongly of understandings and interpretations of historical sources and archeological remains as well as of the aim of the reconstruction that can be either for a validation of the interpretations or a for further investigation of the ancient machinery design in discovering the design peculiarities and manufacturing procedures. The activity for this work was aimed to produce a prototype that will be used to validate both the design interpretations of the ancient Roman cranes and to have a prototype for testing operation performance that can give more insights and understanding again of the design solutions with the corresponding expertise levels but of ancient usage as referring to the remaining monuments and constructions of the Roman empire.

Figure 8 summarizes the multidisciplinary activity that has been planned for a proper identification of a reference design of ancient Roman crane with Vitruvius type characters in order to develop a design solution feasible for a reconstruction that can be a demonstrator both of the design and operation of such an ancient Roman crane. 


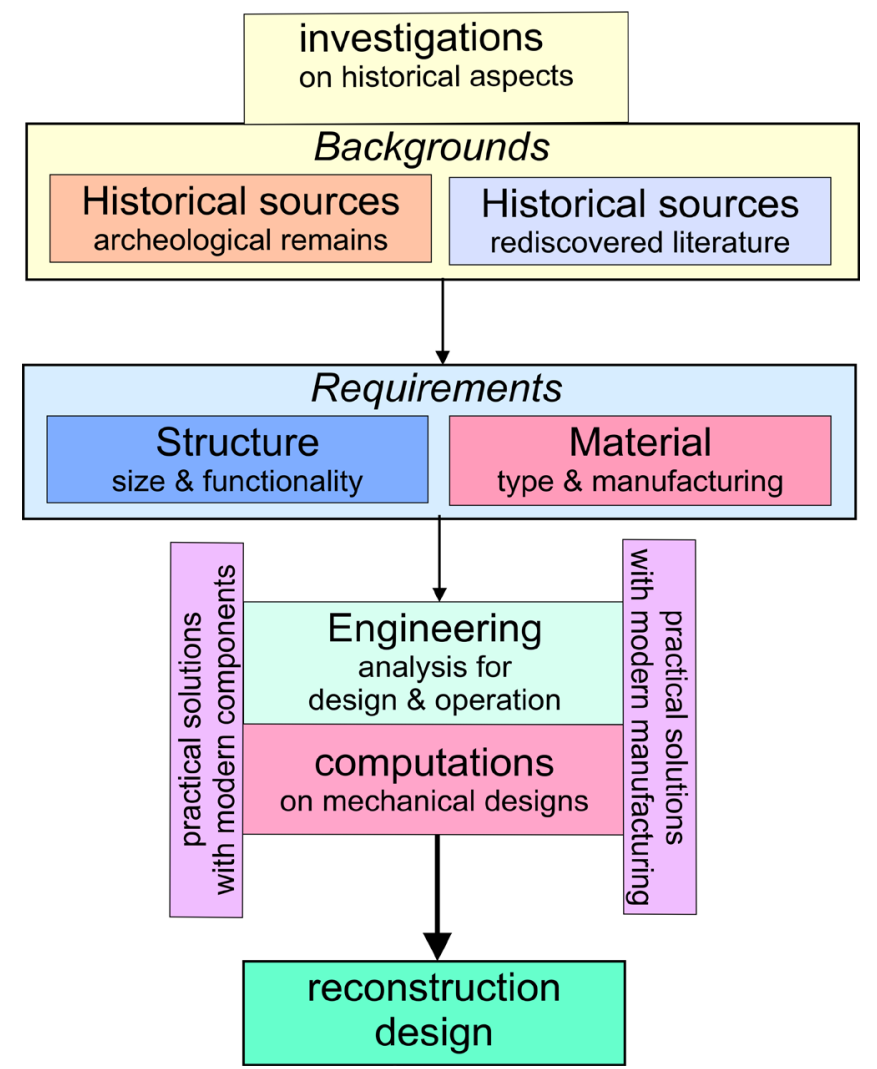

Figure 8. A flowchart of activity plan for modern reconstrcutions of ancient machines.

With reference to Figure 8, the activities that were carried out to design and then to build a prototype of a Roman crane according to the indications of Vitruvius are focused on four main aspects, namely the study and historical research on constructive and functional evidences, definitions of design requirements in terms of structure and materials, design activities with numerical evaluations and definitions keeping in mind aspects of practical feasibility, and reconstruction technologies with characterizing solutions. As far as historical research is concerned, they were based on analyzes of archaeological findings and literature sources as reported in the previous section in order to identify a typical functional structural model for a Roman crane in operation for the handling of stone blocks of at least one ton and to verify its functionality according to its historical fidelity with what was necessary for the construction of demanding works such as the Trajan column for which specific reference was made for the purposes of a museum exhibition. This activity required not only a multidisciplinary project definition but also efforts in terms of design and functional requirements that were better defined in the next step of the activities. These requirements are focused on the definition of the structure in terms of composition not only for dimensional and functional aspects but also in terms of functionality with the elements characterizing the operation of a crane for lifting and handling large stone blocks in constructions of a certain commitment such as 
the Traian column. The definition of the elements characterizing the reconstruction design of a Roman crane were defined as a result of previous historical research defining the supporting structure of the crane as well as the elements of the hoist and the capstan of the crane with a conceptual design shown in Figure 9. In this phase, together with the definition of the elements and their dimensions, attention was also addressed to the choice of materials according to the manufacture possible at the time of the Roman Empire as well as to a modern construction that can simulate the aspects in ancient technologies. Therefore, a study was also carried out on the wood essences to be chosen for the various elements of the crane and also particular attention was dedicated to how to make the connections both in the load-bearing elements and in the details with the use of solutions in accordance with the historical indications that are based on wood joints between the wooden components and a limited use of metal materials as iron nails and bronze pins.

As a consequence of the historical analyses and the identification of the design and functional characteristics also in terms of requirements, we proceeded with a design using solutions with components and materials, albeit of modern technology, with production characteristics in accordance with the availability and possibilities in antiquity. This design phase was developed according to modern techniques making checks in structural and operational analysis with also modern calculation algorithms but always with the aim of deducing practical solutions that could be feasible in ancient times even if using modern components and processes of modern production. The result of this activity, which is also multidisciplinary, with reiterations in multidisciplinary evaluations and discussions to take into account historical aspects and technological feasibility, has led to the definition of a constructive prototype which is summarized in the conceptual scheme of Figure 9. The reconstruction of the Roman crane of Vitruvian type therefore required a cultural synthesis work also as of purely humanistic characters but with synergies in the more purely technological aspects of the machines and their construction. It is to note that this multidisciplinary need was satisfied with a team including historians, archaeologists, architects, and engineers, as well as workers in woodworking and reconstructions of ancient machines.

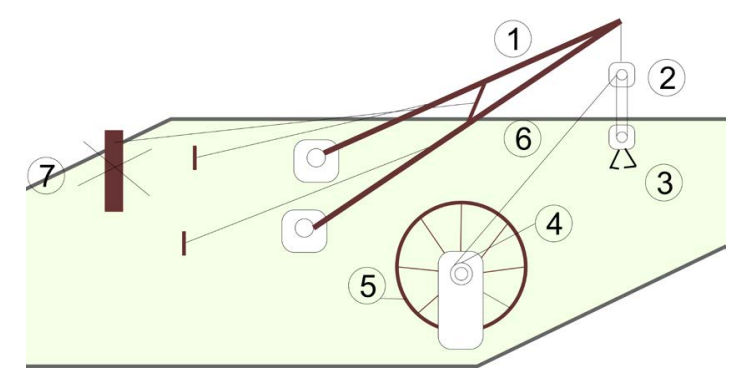

Figure 9. A concpetual scheme of reconstruction design of an ancient Roman crane with main components:1: crane beams; 2 pulley system; 3: load grasping tool; 4: rope axel-drum; 5: calcatoria wheel; 6: rope ; 7 capstan). 
In Figure 9 the conceptual drawing indicates the essential but also design elements of the system that was designed and finally rebuilt with the characteristic elements of a Vitruvian Roman crane to lift and handle high loads of the type that might be necessary for the assembly of the Traian column in Rome. Figure 9 shows the essential structure with two supporting beams which is controlled by a capstan governing its inclination by means of a rope since the structure is hinged to the ground also with an adequate counterweight to ensure its stability. The part linked to the load lifting is characterized by a system of pulleys which are activated by means of the corresponding rope by a calcatoria wheel that moves the drum on which the rope is wound. Figure 9 also highlights the overall dimensions of such a Roman crane that can be assembled with a calcatoria wheel also inside the supporting structure with an axis jointed on the same supporting structure. The conceptual design as in Figure 9 is limited by the dimensional requirements according to the choice of materials, especially wooden ones and of the components that should be similar to those actually used in Roman times. One of the major constraints therefore has also been recognized in the rope in terms of its dimensions, material, and the methods of its production.

In summary, in this work the above-mentioned requirements were elaborated to build a prototype as a reconstruction of an ancient Roman crane of Vitruvius type near to the Haterii design that could have been used for large constructions like the Colosseum in Rome or the Traian column as reported in (Di Pasquale, 2019) referring to the museum exhibition in Florene in the summer of 2019.

\section{Considerations and Models for a Reconstruction Design}

The design activities were carried out to create a demonstrative but also functional prototype in accordance with the conceptual proposal that is illustrated in Figure 9 referring to the analyzed requirements in section 3 . The modeling and dimensional design were focused on the components that are represented in Figure 10, i.e. the beams of the two-arm supporting structure 1, the pulley system 2 for lifting the load, the drum 4 for winding the lifting rope, the calcatoria wheel 5 for driving the drum 4, and the rope 6 for lifting loads that is also used for maneuvering the supporting structure 1 . For the purpose of reconstructing a

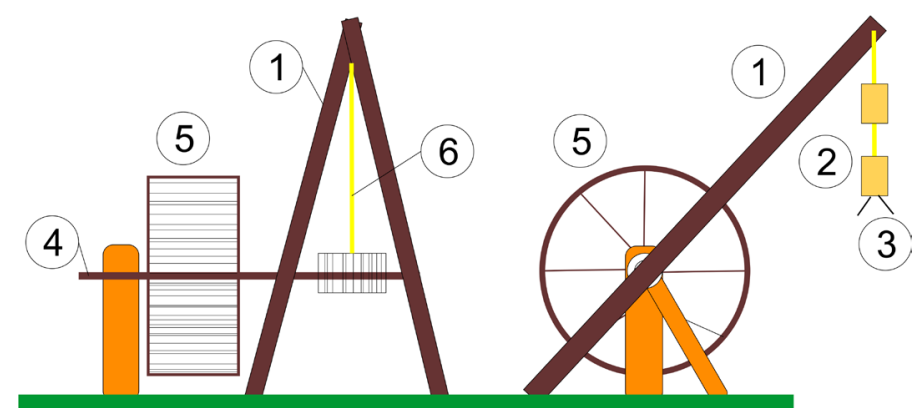

(a)

(b)

Figure 10. A design model for reconstrucion of an ancient Roman crane with calacatoria wheel: (a) Front view; (b) Lateral view. 
demonstrator useful for a museum exhibition, it was decided not to include the capstan 7 for the inclination of the supporting structure 1 and for the load gripping system 3 it was decided to use a reconstruction of clamp for marble stone blocks. In both Figure 9 and Figure 10 the ropes fixing the beams of the supporting structure in the ground are not represented but they were considered as the one from the design results for the rope 6.

Using the model in Figure 10 the beams of the supporting structure and structure of the calcatoria wheel have been designed in wood for a reconstruction with modern modeling calculations also with FEA (Finite Element Analysis) algorithms to size and to verify the dimensions of the parts from an analysis of force and stress in static conditions, considering the modest rotation speed that it can be activated by one or more or two calcators. The beams were designed with $7.00 \mathrm{~m}$ length as related to a suitable height for the assembly construction of the Traian column.

The constructive solution of the calcatoria wheel has been a source of long discussions especially for deciding the number of spokes which in archaeological sources vary between 11,12 , and 13 . In the solution that was adopted for the reconstruction, 13 spokes were implemented as in the Haterii crane. However, it can be noted that a practical solution refers to the even number of spokes for a simple regular division of the wheel circumference. It has also been thought that the odd number is justified by an elliptical rather than circular shape of the wheel perhaps for greater efficiency rotation in specific configurations (such as for example in elliptical sprockets in today's racing bikes).

The dimensions of the calcatoria wheel were actually decided considering the presence and action of at least one calcator and therefore with a radius greater than $1.60 \mathrm{~m}$ (actually $2.0 \mathrm{~m}$ was chosen) and a width of $100 \mathrm{~cm}$. A characteristic aspect is the internal table pavement on which the calculator acts during his walk to give a thrust action that produces a torque for the rotation of the wheel according to the diagram of Figure 11. Figure 11 shows a model of this situation in which a calcator performs a not excessively long walking step $\mathrm{p}$ to perform the thrust function that is indicated with the force $\mathrm{F} 1$ when he is still with the rear foot in contact with the pavement with only part of his weight with a force F2. Assuming that the force F2 is of modest entity as compared to the force F1 because the calcator is extended on the thrust F1 and also that F2 is on the vertical

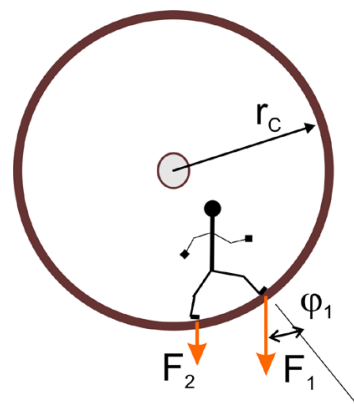

Figure 11. A model for analysis and design of forces in calcatoria wheel. 
direction passing through the center of the wheel with radius $r_{C}$, the driving action of $\mathrm{F} 1$ determines a torque which can be expressed as

$$
\mathrm{M}=\mathrm{F}_{1} \mathrm{r}_{\mathrm{C}} \sin \varphi_{1}
$$

with $\sin \varphi_{1}$ evaluable as

$$
\sin \varphi_{1}=\mathrm{p} / \mathrm{r}_{\mathrm{C}}
$$

The characterizing aspect of this drive is actually the length of the step $\mathrm{p}$ of the calcator and the possibility of a decisive F1 thrust with regularity during the rotation of the wheel itself. Therefore, small steps can be provided in the internal floor of the wheel that facilitate both the regularity of the walking thrusting step and the contact of the foot in push. It was decided a regular step equal to $50 \mathrm{~cm}$. With this dimensioning and considering a maximum F1 thrust equal to $800 \mathrm{~N}$ (equal to the weight of the calcator plus about $30 \%$ ), a drive torque $\mathrm{M}$ is obtained equal to $400 \mathrm{Nm}$, with only one calcator, as the driving torque for the rope drum of resulting in a tension of $4000 \mathrm{~N}$ of rope tension.

With reference to the model in Figure 12, the pulley system has been designed and verified with modern formulations relating to the operation of these systems, by looking at the mechanics that actually could be used in the time of the re-discovery of the work of Vitruvius and referring other classical works, as for example reported not only in the liber X but also in the Mechanicorum Liber of Guidobaldo Del Monte, (Del Monte, 1577). In particular, the pulley and the rope have been calculated by using the model of static equilibrium in Figure 12 to express

$$
\mathrm{T}_{0}+\mathrm{T}_{1}+\mathrm{T}_{2}=\mathrm{F}
$$

with the condition

$$
\mathrm{T}_{\mathrm{i}}=\mathrm{kT}_{\mathrm{i}+-1} \quad \mathrm{i}=0,1
$$

Considering the stiffness coefficient $\mathrm{k}$ of the rope equal to 1.015 allows the identification of a suitable hemp rope with three strands within a modern production that is also used for the historical Italian sailing ship Amerigo Vespucci. Referring to a catalog of a rope production, (STMC, 2019), a rope with a diameter of $24 \mathrm{~mm}$ was selected that according to Equations (3) and (4) ensures a tension capacity of 4270 daN which allows a payload capacity of about 13 tons with a suitable pulley block. Considering the tension in the rope with the above-mentioned load capacity, the structure of a wood pulley block has been dimensioned under
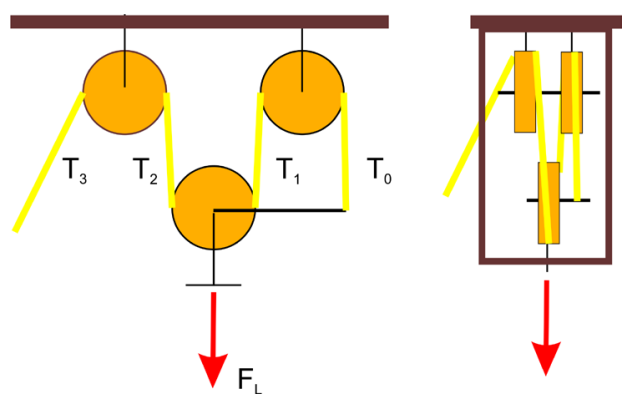

Figure 12. A model for analysis and design of forces in. pulley system. 
shear stress with a thickness of about $5 \mathrm{~cm}$ and the bronze axle of the pulley is sized with a diameter of $4 \mathrm{~cm}$, also referring to the archeological remains as the one in the imperial ship in Nemi, Figure 3(a).

The final design results were used to define the design solutions as reported in the executive drawings in Figure 13 as per the calcatoria wheel and the pulley blocks.

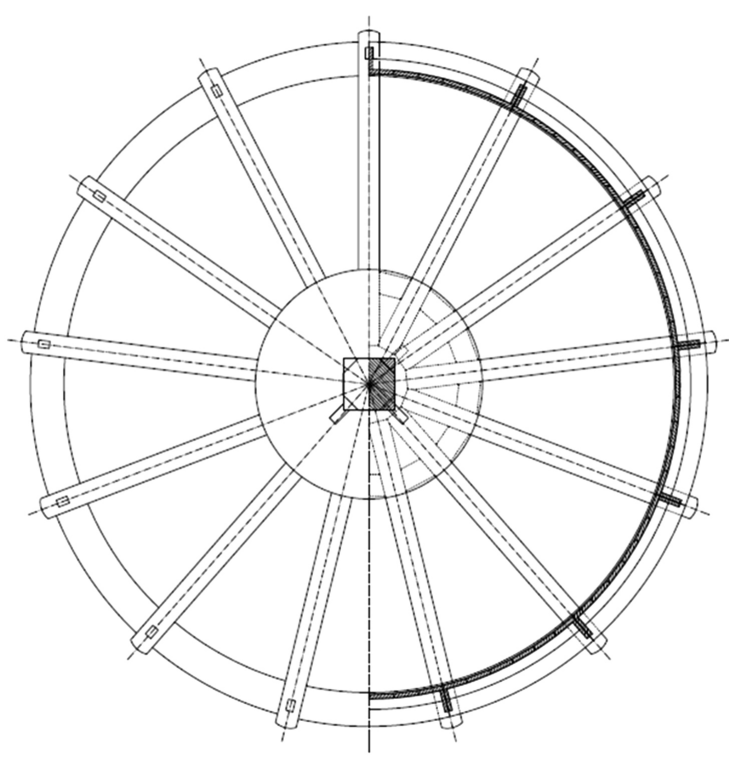

(a)

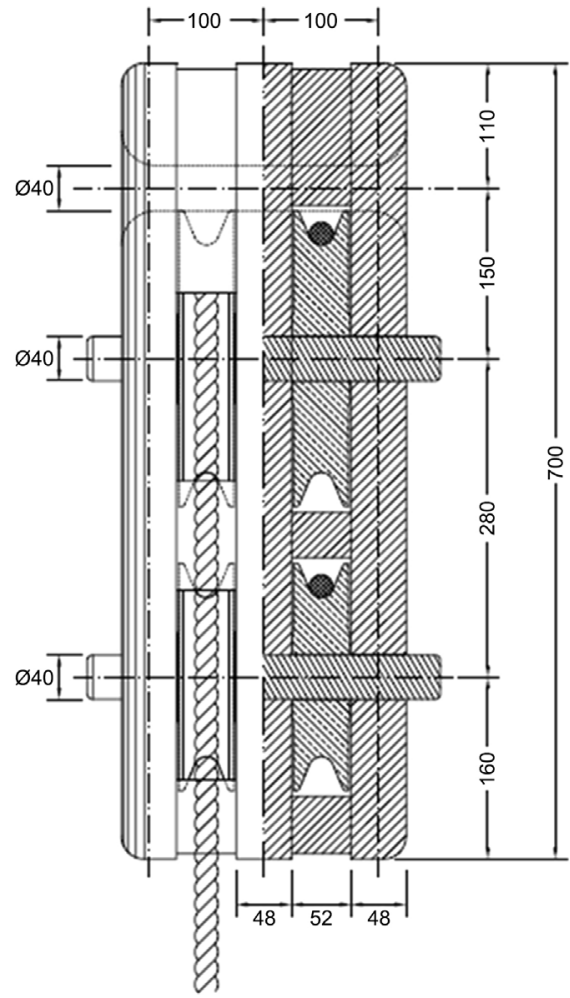

(b)
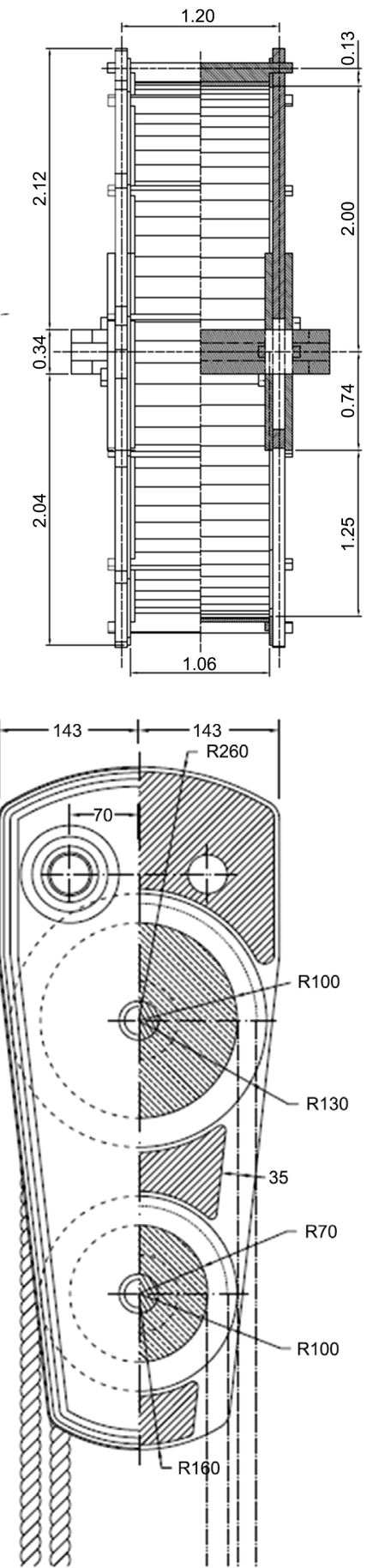

1

Figure 13. Executive drawing for reconstruction of: (a) Calcatoria wheel; (b) A pulley. 
Regarding materials, thanks to studies and considerations on the materials used and available in ancient Roman technology and referring previous experiences reconstructions of Roman machines as reported for example in (Ceccarelli et al., 2019), the following selections of wood species were made:

- calcatoria wheel with internal structure, external circumferences, spokes made of oak rods and the pavement for calcators made of fir bars

- beams of the crane in oak with the ground counterweight rod made of cypress

- the pulleys and the body frame made of the holm oak blocks

- the drums of the winches made of walnut wood

- the assemblies were made of joints and wedges with wooden parts and if inevitable, wrought iron nails were used to fix parts

The design and construction of the Roman crane prototype is based on considerations that were inspired by archaeological studies and analysis of archaeological findings together with the examination of the literature especially with reference to the work of Vitruvius in Renaissance reproductions when combined with engineering considerations of practical implementation and usage of a rebuilt crane as demonstrator.

In summary, the demonstrator Roman crane of the Vitruvius \& Haterii design have been sized with beams of length of 7.00 meters and the calcatoria wheel with a diameter of $4.0 \mathrm{~m}$, which both can be considered characteristic data for an ancient Roman crane in activities for large civil constructions. The reconstruction has been designed for a safe load capability of 12 tons as per an application in the assembly work of the Trajan's column using two calcators at least.

\section{A Prototype Reconstruction}

The reconstruction design was elaborated by considering the above-mentioned requirements and constraints mainly in taking into account materials similar to those available at the time of the investigated ancient Roman cranes. Thus, main materials were searched with proper woods for the structures and natural fibers for the ropes, as main design aspects for a reconstruction of an ancient Roman crane.

Figures 14-16 shows the built prototype of an ancient Roman crane as results of the previous discussed activities and design choices.

The feasibility of the prototype was tested successfully also at the exhibition held in Florence Uffizi Museum from June to October 2019 as in Figure 14 for explaining the construction of the Traian column remaining in Rome, (Di Pasquale, 2019).

The reconstructed crane as a demonstrator prototype is characterized as per practical modern-like functionality by two one-piece long beams that are connected at the top with axles that are used also to carry the main pulley blocks and are counterbalanced at the bottom by an heavy frame beam that help the fixing of the crane on the ground through other ropes. The drum for the rope of the load lifting is assembled among the two long beams with the axle that is driven by the calcatoria wheel that is installed aside the crane beams as an independent motion driver. 


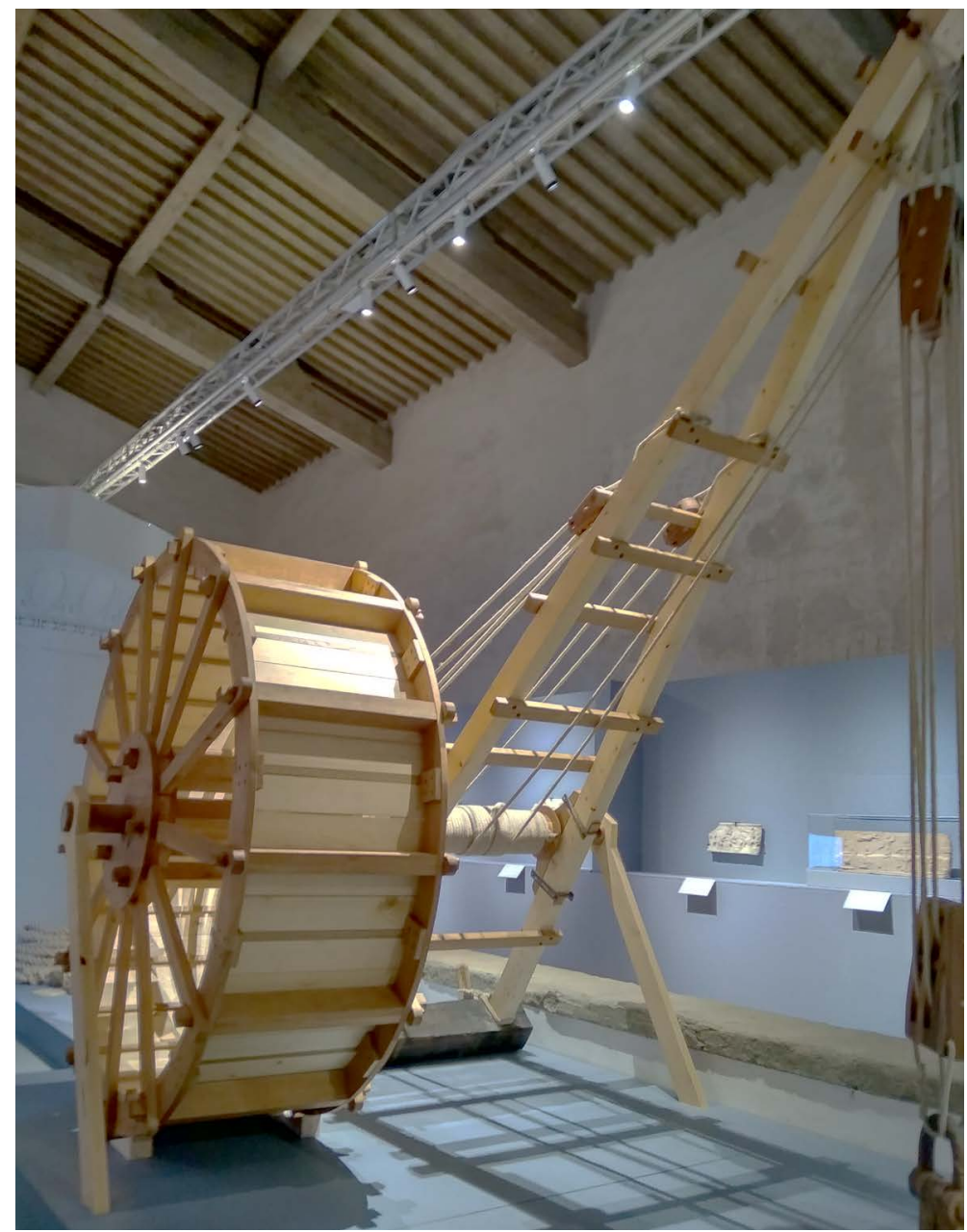

Figure 14. The reconstrucuted ancient Roman craneatthe exhibition in the Limonaia building of Pizzi palace museum in Florence in June-Ocotber 2019, (Di Pasquale, 2019).

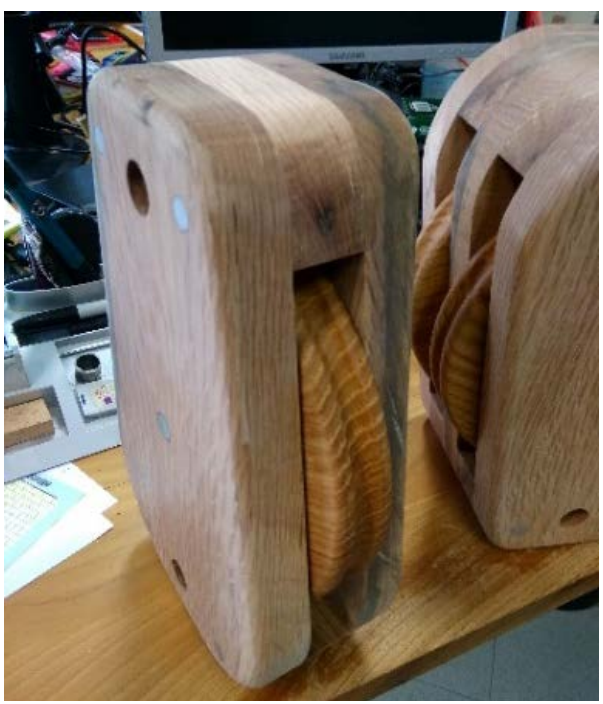

(a)

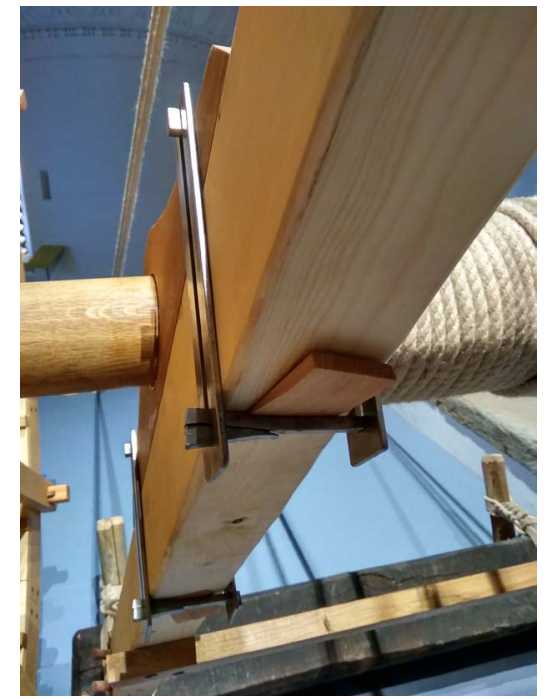

(b)

Figure 15. Details of the crane reconstruction in Figure 14: (a) of a pulley block; (b) of a axel connection. 


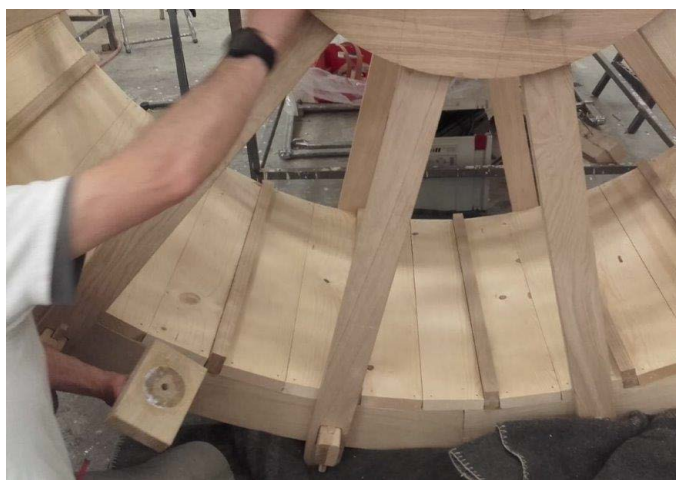

(a)

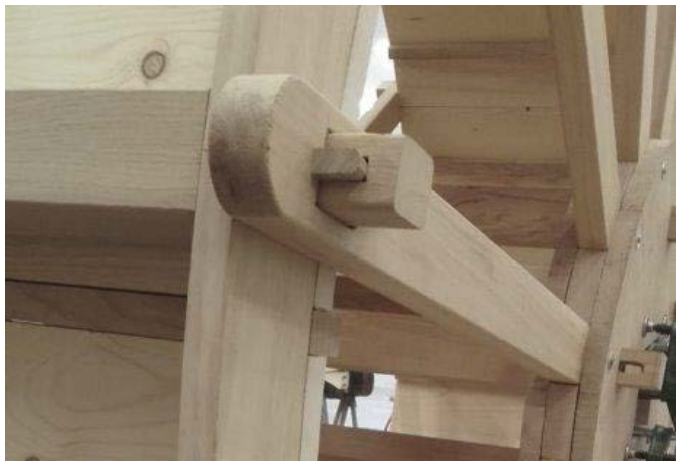

(b)

Figure 16. Details of the crane reconstruction in Figure 14 in the calcatoria wheel: (a) The pavement with small step rods; (b) The spoke connection.

During the manufacturing of the reconstructions, particular attention was paid to the mechanics of the transmission both in the pulley blocks and rope elements and in the calcatoria wheel for carrying out the lift and movement of weights loaded on the terminal element of the rebuilt crane. The design of the pulley blocks and of the relative lifting system with hoist ropes was carried out both with reference to a simple but effective modern mechanics by taking into account the archaeological findings of the block available at the museum of Roman imperial ships in Nemi and from the artistic representation on the basso-rilievo of the Haterii tomb. Details of the built solutions are shown in Figure 15. In Figure 15(a) the full wood construction of the pulley blocks is shown and in Figure 15(b) the wood connections are illustrated as a characteristic choice in the reconstruction to reproduce ancient solutions. In particular, the connections of the supporting frame of the drum axel have been manufactured to fix the wood frames by means of wrought iron pieces that are connected with wedges both again in iron and wood, as shown in Figure 15(b).

Similarly, the construction of the calcatoria wheel was manufactured as with the details in Figure 16 according to the above-discussed design arguments referring to various archaeological findings of Roman calcatoria-driven cranes by taking into account of functional design solutions both in terms of construction and operational efficiency, such as for example in defining the distance of the internal step rods for foot thrust by the calcator operators. Particular attention 
was addressed in the assembly solutions with wedges and wood joints to ensure both robust connections and correct precise mechanical design according to the design drawings.

Thus, the reconstructed crane is a wood-based Roman crane for large constructions with a design and manufacture that is inspired to the third type of Vitruvius load lifting machines referring to archeological sources mainly of the Haterii crane with the aim to be a successful experience of reconstruction of an ancient Roman machines as a demonstrator in the specific large construction as for the Traian column and a first research result in exploring ancient Roman technology with practical function.

\section{Conclusion}

The design and reconstruction of an ancient Roman crane of Vitruvius-Haterii type is presented in the form of a full-scale prototype as based on considerations that are inspired by archaeological studies and analysis of archaeological findings together with the examination of literature especially with reference to the work of Vitruvius in Renaissance reproductions in combination with engineering considerations for practical manufacturing and usage of the crane prototype. The protype demonstrator has been built with characteristics of the third type of Vitruvius cranes referring to Haterii crane reproducing the load lifting capability for assembling works related to the construction of Traian column in Rome with an overall size of 7.0 meter tall and load capacity of 12 tons.

\section{Acknowledgements}

The author wishes to thankfully acknowledge Gian Giacomo Martìnes (former officer of Italian Ministry for Cultural Heritage), Cinzia Conti (former officer of Soprintendenza Archeologica di Roma), Pier Gabriele Molari (former professor at University of Bologna), Fabio Sabbadini (engineer), Matthias Bruno (archeologist), Alessandra Carriero (engineer), Anna Maria Saccomanno (architect at Technical Office of Rome city), Giovanni Di Pasquale (director at Galileo Museum in Florence) for the collaboration in the work of design and analysis of the reconstruction of the Roman crane structure. Particular thanks are expressed to the staff of Opera Laboratori Fiorentini Ltd in Florence that has operated to build the prototype that has been first exhibited in June-October 2019 in Florence at the Limonaia building of Uffizi Museum.

\section{Conflicts of Interest}

The author declares no conflicts of interest regarding the publication of this paper.

\section{References}

Borgnis, G. A. (1818). Traite des Machines-Motion of Load. Paris: Bachelier. (In French)

Burstall, A. F. (1963). A History of Mechanical Engineering. New York: Pitman Publ.

Capocaccia, A. (Ed.) (1973). History of Technique-From Prehistory to the Year One 
Thousand. Turin: UTET. (In Italian)

Ceccarelli, M., \& De Paolis, P. (2008). A Brief Account on Roman Machines and Cultural Frames. In H. S. Yan, \& M. Ceccarelli (Eds.), Proceedings of HMM2008-The Third IFToMM International Symposium on History of Machines and Mechanisms (pp. 83100). Dordrecht: Springer. https://doi.org/10.1007/978-1-4020-9485-9 7

Ceccarelli, M., Ceccarelli, S., Conti, C. E., \& Martines, G. (2019). Ball Bearings from Roman Imperial Ships of Nemilake. Advances in Historical Studies, 8, 115-130. https://doi.org/10.4236/ahs.2019.83009

Cesariano, C. (1521). Di Lucio Vitruvio Pollione De architectura libri dece ..... Como: G. da Ponte.

Cigola, M., \& Ceccarelli, M. (2014). Marcus Vitruvius Pollio (Second Half of the Ist Century B.C.). In M. Ceccarelli (Ed.), Distinguished Figures in Mechanism and Machine Science (Vol. 26, pp. 307-344). Cham: Springer. https://doi.org/10.1007/978-94-017-8947-9_15

Cigola, M., \& Ceccarelli, M. (2016). Machine Designs and Drawings in Renaissance Editions of de Architectura by Marcus Vitruvius Pollio. In F. Sorge, \& G. Genchi (Eds.), Essays on the History of Mechanical Engineering (pp. 291-309). Cham: Springer. https://doi.org/10.1007/978-3-319-22680-4_17

Del Monte, G. (1577). Mechanicorum Liber. Pisauri: Apud Hieronymum Concordiam. (In Latin)

Di Pasquale, G. (Editor) (2019). The Art of Constructing a Masterpiece: The Traian Column. Florence: Giunti. (In Italian)

Fleury, P. (1993). The Mechanics if Vitruvius. Caen: University Press of Caen. (In French)

Fra' Giocondo (1513). Vitruvius iterum et Frontinus a Iocundo. Firenze: F. Giunta. (In Latin)

Galli, M., \& Pisani Sartorio, G. (Eds.) (2009). Machina: Technologies of Ancient Rome. Rome: Palombi Editore. (In Italian)

Martines, G. (1999). Machines in Constructions for Lifting Weights, from Antiquity, in Middle Ages, in Centuries XV and XVI. Annals of Architecture, 10-11, 261-275. (In Italian)

Meighorner-Schardt, W., \& Blumenthal, H. (1989). Wheel Reconstructions for a Roman Crane. Bonn: Bouvier GmbH. (In German)

Molari, P. G., Bruno, M., Conti, C., \& Martines, G. (2016). Haterii Crane: Analysis of the Winch and Hoists. In Proceedings of 2nd Italian Conference on History of Engineering (pp. 329-341). Naples: Cuzzoli Publ. (In Italian)

Rossi, C., Russo, F., \& Russo, F. (2009). Ancient Engineers' Inventions-Precursors of the Present. Cham: Springer.

Rusconi, G. A. (1660). De Architecure. Venice: Nicolini. (In Italian)

Russo, F., \& Russo, F. (2009). Techne: The Leading Role of the Military Culture in Technological Evolution-Classical Age. Rome: Rivista Militare. (In Italian)

Shaw, J. W. (1967). A Double-Sheaved Pulley Block from Kenchreai (Plates 76-78). Hesperia: The Journal of the American School of Classical Studies at Athens, 36, 389-401. https://doi.org/10.2307/147369

Singer, C., et al. (Eds.) (2012). History of Technology (Vol. 2). Turin: Boringhieri. (In Italian)

STMC (2019). Catalogue of Ropes. Stabilimento Militare Produzione Cordami Castellammare di Stabia. (In Italian)

Ucelli, G. (1950). The Ships of Nemi. Roma: Istituto Poligrafico dello Stato. (In Italian) 